\author{
Душанка С. ЗВЕКИЋ-ДУШАНОВИЋ* \\ Универзитет у Новом Саду \\ Филозофски факултет
}

Оригинални научни рад

Примљен: 24. 09. 2018.

Прихваћен: 14. 02. 2019.

\title{
О МОДАЛНОЈ РЕЧЦИ ВАљДА У КОНТЕКСТУ
}

\begin{abstract}
Речца ваљда припада семантичкој групи лексема којима се, првенствено, исказује епистемичка модалност. У раду се, на корпусу савременог српског језика, утврђују места која може заузимати на скали уверености, испитују њене семантичке вредности које добија у зависности од контекста и анализира се утицај различитих типова модалног извора на њену интерпретацију. Поред тога, указује се и на синонимијске односе који се могу успоставити између речце ваљља и њој сродних модалних показатеља.

Кључне речи: речца ваљда, епистемичка модалност, булетичка модалност, семантика, српски језик.
\end{abstract}

1. Увод. Речце представљају веома хетерогену врсту речи. Као посебан тип обично се издвајају оне које имају модално значење. А. Белић, говорећи о одношајним речима, издваја групу речи којима се „износи субјективни став нечији о вези појмова у реченици” (Белић 1941: 137) и назива их „уметнутим модалним одношајним речима или речцама”. И у потоњој литератури ова се група речи дефинише на сличан начин, а у њу се сврстава и речца валда. ${ }^{1}$

За подробнији опис семантике ове речце потребно је одредити какво модално значење она носи. Ако се има у виду да се ова речца у РСЈ одређује као: речца за изрищање оправдане, природне претпоставке, уверености у нешто и наводе се синоними вероватно, по свој прилици, свакако, јасно је да је за њену анализу релевантна епистемичка модалност. Овим се модалним типом, различитим језичким средствима, исказује степен уверености у истинитост пропозиције. Уграђујући епистемички показатељ у исказ, говорник се

\footnotetext{
*dusazd@ff.uns.ac.rs

** Рад је настао у оквиру пројекта Стандардни српски језик: синтаксичка, семантичка и прагматичка истраживања (бр. 178004), који финансира Министарство просвете, науке и технолошког развоја Републике Србије.

${ }^{1}$ Речца ваљда налази се на списку модалних речци (партикула) и у граматикама М. Стевановића (1964: 397), Ж. Станојчића и љ. Поповића (2002: 128), П. Мразовић (Мразовић 2009: 468), П. Пипера и И. Клајна (2013: 215).
} 
у мањој или већој мери дистанцира од истинитости пропозитивног садржаја. П. Пипер (2005: 643) овај тип модалности одређује на следећи начин: „епистемичка модалност представља степеновану квалификацију уверености говорног лица у истинитост онога што је означено исказом”. Према Џ. Бајби и сарадницима (Бајби и др. 1994: 180) епистемичка модалност обично обухвата могућност (possibility), вероватнићу (probability) и увереност, односно извесност до које се долази на основу извођења закључка (inferred certainty). К. Боје (Боје 2016: 117) даје сажету дефиницију епистемичке модалности према којој она покрива средства која исказују ниво епистемичке подршке пропозицији, односно ниво уверености у пропозицију. Ф. Р. Палмер (Палмер 2001: 8) сматра да епистемичком модалношћу говорник изражава свој суд о фактуалном статусу пропозиције. Према његовој систематизацији постоје три типа судова (Палмер 2001: 24):

- $\quad$ који изражавају несигурност (спекулативни, Speculative),

- $\quad$ који се односе на закључивање на основу уочљивих доказа (дедуктивни, Deductive),

- $\quad$ који представљају закључивање на основу онога што је општепознато (асумптивни, Assumptive).

У студији о епистемичкој модалности у енглеском и српском језику И. Трбојевић-Милошевић (2004) илуструје скаларну природу епистемичких модалних прилога представницима тешко > можда > вероватно > сигурно. Ауторка наводи и њихове синонимијске редове - тешко: једва, мучно...; можда: лако, ваљда...; вероватно: могуће, канда...; сигурно: несумњиво, извесно, бесумње, наравно, свакако, зацело... (Трбојевић Милошевић 2004: 170). И П. Мразовић речци ваљда даје вредност модалне партикуле можда (Мразовић 2009: 472). ${ }^{2}$

Аргумент за сврставање ове речце међу средства за исказивање могућности може бити тај који даје И. Трбојевић-Милошевић за лексему можда. Наиме, она примећује да је једини степен који се не може модификовати (интензификовати или ослабити) онај који је означен прилогом можда: *Beома/врло/потпуно можда је то истина. ${ }^{3}$ Ово правило важи и за речцу ваљда: * Веома/врло/потпуно ваљьа је то истина. С друге стране, приметно је да само значење могућности дозвољава употребу истог модалног индикатора у сложеној реченици у којој су две предикације у супротном односу, што може бити знак нижег степена уверености. У Корпусу савременог српског језика сасвим су уобичајени примери реченичних модела можда $X$, а можда $Y$ и можда $X$, а можда не $X$ :

${ }^{2}$ П. Мразовић указује на њено појављивање и у говорним чиновима као конверзационе партикуле (Мразовић 2009: 505). С том функцијом може имати различита значења међу којима ауторка наводи: жељу да се садржај питања оствари (Вечерас ваљда можеш изаћи?), неверицу (Није ваљда већ стигао!?), одбијање нечије молбе (Нисам ваљда твој слуга да ти чистим ципеле!), прекор (Ниси се ваљда опет свађала!? Ниси ваљда опет био у кафани!?).

${ }^{3}$ Ово објашњава тиме да „MOŽDA na skali epistemičke vrednosti zauzima isto neutralno mesto kao odrični oblik faktivnog glagola ZNATI ili futur II (Трбојевић Милошевић 2004: 171). Односно, да се на скали налази на „пола пута”, те не може бити више или мање на пола пута. 
Можда је ово трајало само један трен, а можда и много дуже (fa2-david01.txt)

Можда је проблем, а можда и није (Parking-is.xml)

Овакав тип реченица с речцом ваљда није забележен у корпусу. Односно нема примера типа *ваљда $X, a$ ваљда $Y$ и *ваљда $X$, а ваљьа не $X$, што ову лексему приближава низовима с индикаторима нешто већег степена уверености: *вероватно $X$, а вероватно $Y$ и *вероватно $X$, а вероватно не $X$.

Имајући у виду да се речци ваљьд приписују различити степени уверености, у овом раду настоји се утврдити на који начин контекст утиче на њену интерпретацију и који се синонимијски односи могу успоставити између лексеме ваљда и њој сродних модалних показатеља. Грађу чини 600 примера реченица у којима се појављује лексема ваљда, забележених у Корпусу савременог српског језика.

2. Лексема ваљља у афирмативним исказима. Прикупљени примери показују да се речцом ваљља исказују различити нивои уверености у истинитост онога о чему се говори, али да се она јавља у још неким значењима која нису типично епистемичка, као што су наглашавање истинитости с примесама негодовања и изражавање наде у остваривање именоване ситуације.

2.1. Овом се лексемом најчешће исказује несигурност. Говорник спекулише о истинитости пропозиције немајући поузданих доказа. Исказ који настаје додавањем лексеме ваљља јесте ментални конструкт спекулативног карактера. Модални извор је искуство говорника. Степен уверености исказан овом лексемом ближи је модалној речци можда када нема доказа или када су они недовољни да би се могло поузданије закључивати о истинитости пропозиције. Ближи је модалном прилогу вероватно када искуство и докази повећавају вероватноћу да је пропозиција истинита. Ниво уверености је, дакле, релативно низак, креће се на релацији између ова два модална оператора, што се види у следећим примерима:

Уочи премијера би се ућутао, ваљда је тако мислио да пробуди у твојој мајци грижу савести (velikic-sr.xml); ...јединог певача без имена (велики број их је без презимена, естрадна мода, ваљда) (poli010730.txt); На питање зашто стално излажу заједно, Шиба Фимић каже да је то, ваљда, део судбине која им је још у детињству одредила духовну блискост (poli001029.txt); Док је био у Београду, осетио је да му се одузимају десна нога и десна рука. Са главом све у реду, али ваљда је неки живац (poli010130.txt); Добрача у својој историји преживљава тешке дане, ваљда најтеже од времена њеног војводе Јове Добраче (poli010629.txt); Људи ћуте. Ваљда мисле да је тако здравије (poli000903.txt); Некад недодирљиву зграду окупирали су новинари и домаћи и мноштво страних. Сматрају је ваљда савршеним склоништем (poli001025.txt); Иако притиснут великим дуговима, он је ваљда први оружани пљачкаш у престоници кога није интересовало злато и накит жртве (poli010515.txt); Није лако укратко представити Милутина Јовановића Ђоку из Уба. Он je, ваљда, најпознатији Убљанин (poli010418.txt); Нада и Никола Јовић први су завршили своју кућицу. Доста им је ваљда било селидбе (poli010319.txt); Све њих је велика мука натерала да оду из Србије, а ваљда им је било природно да дођу на Крф, који свакако припада и нама (poli001218.txt); Наши стари су, изгледа, више од нас 'терали комендију'. Ваљда су имали и више повода за то (poli010225.txt).

2.1.1. Неретко говорник износи своја размишљања о узрочно-последичној вези међу појавама и дешавањима. Лексема ваљда појављује се испред 
узрочне конструкције означавајући несигурност у тумачењу узрока дате ситуације.

Зашто генерални секретар не показује толико полетности и елана као што показује његов колега из Брисела, мада не баш у потпуности? Ваљда због исцрпљености (poli000806.txt); У већини од седам општина стизале су вести да на почетку гласања није било одвише раноранилаца, ваљда и због мразева и поледице у овом крају (poli001224. txt); ...не могу (ме) спречити ни претње које ми упућују појединци, ваљда из страха за сопствену слободу (poli010111.txt); Људи су, ваљда због лоше безбедне ситуације, оценили да им овде није будућност (poli001227.txt); Мићуновић је (...) једно време уживао симпатије и изван својих страначких просторија, ваљда због наглашене седативне смирености (poli010222.txt); Остављамо их, с мало нове наде, у тим 'Барицама', како зову тај део Брестача, ваљда због бара испред кућа, чим мало закиши (poli010325.txt); Ваљда су од вина сви Вукашиновићи, од унуке Тање до деде Милана, здрави и румени! (poli010214.txt); Од свих места где сам живела најлепше је то село, ваљда што сам ту провела младост (poli001230. txt); Џорџ Прис из Велике Британије је осигурао свој аутомобил за само један пени, ваљда зато што ситнији апоени не постоје (poli001127.txt).

\subsection{2. Ова се речца често појављује и у синтаксичким конструкцијама} којима се износи закључак, означавајући несигурност у исправност закључка. Основу закључивања представља знање изнето у тексту који претходи. Речца ваљда у непосредном је контакту са заменичким прилогом зато, појављујући се и испред и иза њега.

Само песници, ти предани маштари, заточници сумње, или критичког просуђивања света, још остају приврженици мита о катарзичним својствима песничког говора. Зато, ваљда, и стварају (poli001107.txt); ...у приватно издаваштво ушао (je) међу првима, још 1987. године, улажући у овај посао целокупну своју имовину, стечену радом у иностранству. Зато га, ваљда, и називају 'џентлменом српског издаваштва' (poli010104.txt); ...данас је у Бујановцу освануо прохладан, али леп и сунчан дан. Ваљда и зато Бујановчани, озарених лица и, чини се, оптимистичније гледају своју будућност (poli010204.txt); Функционалност, лепоту и изузетан положај те виле знао је често да хвали Александар Ранковић, па је ваљда зато она, у причама, помињана као Лекина резиденција (poli010330.txt); Искуства развијених земаља показују и то да економски развој више зависи од технологије него од капиталног улагања. Зато ваљда западни свет и улаже толико у заштиту интелектуалне својине (poli010729.txt).

2.1.3. Забележени су и примери у којима говорник спекулише о циљу или намери остваривања ситуације. Речца ваљда јавља се непосредно испред таквог типа клаузе означавајући говорникову несигурност у своју процену циља или намере с којом се предузима нека радња.

Савремена литература се бави или простим описивањем, што ме никад није занимало, или неким измишљеним, непостојећим ликовима, то је неаутентичност, што бизарније, ваљда да би било занимљиво (velikic-sr.xml); Поред ових 'часника', потписала се и Хелена Мандић, као шеф правног одјела ове комисије, ваљда да потврди да је све по закону силе (poli000820.txt); Ваљда да не буде представљено као њихово, многи познати политичари из претходне власти куповали су те апартмане на имена својих жена или блиских сродника (poli001124.txt); Ражнатовић је још рекао да су у кошаркашку кућу у којој је седница одржана доведени и 'неки типови' мрачног изгледа, ваљда да неког ту заплаше (poli010711.txt).

2.1.4. Посебну групу примера представљају они у којима речца ваљда уноси несигурност која се односи на непоузданост сећања. У таквим приме- 
рима ова је речца заменљива изразима типа: ако се добро сећам, ако добро памтим:

Назире се и Јанкова клисура. Кажу да носи назив по оном Јанку, (ваљда Хуњадију) (poli000813.txt); „Зове се Чедомир Стошић”. Опет неко од дечака прокоментариса: „Ма не, он се такој зове, него како га викав”? Странац невољно изусти: „Ваљда Чеда Мотка” (poli001226.txt); Напоменуо бих да је на једној конференцији, ваљда у јануару ове године (poli010306.txt); То је било ваљда године 1858, баш кад је рођен Пупин (poli010429.txt); ...кроз Смедерево је некада само прошла, ваљда на некој екскурзији (poli010507.txt).

2.1.5. У следећим примерима говорник даје процену дужине трајања неког периода, количине неке материје и сл. Речцом ваљьа ограђује се од поузданости тврдње.

Неки Клеј Фрејзер још и може да се поднесе једном у десет година, али ово чудо траје ваљда месец дана (poli000924.txt); Jep, мере безбедности су такве какве Словенија не памти ваљда од када постоји (poli010615.txt); ... попијена (je) ваљда цела пржионица кафе, уз шлепер 'Хебиних' и 'Биводиних' сокова и воде (poli010607.txt).

2.2. Истинитост пропозиције може се процењивати и на основу уочљивих доказа. Речцом ваљда говорник уноси опрез, он није сигуран да су ти докази довољни за поуздану тврдњу. Постојање визуелних доказа ипак повећава степен уверености, те је у примерима таквог типа речци ваљља, по степену уверености, близак епистемички модални показатељ вероватно, чак и сигурно. Ипак, лексема ваљда носи нешто нижи степен уверености од типичног представника закључивања на основу визуелних доказа као што је очигледно.

Испред једног од бројних бункера, ваљда у брзини, терористи су за собом оставили плински решо, шољице за кафу, џезву и два чајника са чашама, пуно цигарета, два оквира од аутоматске пушке 'калашњиков', пуно метака кинеске производње (poli010516.txt); Лутао сам планином Кукавицом и на једном пропланку набасам на сточно звоно. Жуту ливену бронзу. Ваљда је било на неком овну (poli010610.txt); У сваком ауту само возач, врло често са мобилним телефоном на уву. Ваљда, неки важан пословни свет (poli010420. txt); Горе, на врху махале, где почиње травната коса, испред једне куће столови, око њих столице и пањеви, шољице неиспијене кафе, пећ, лонци, тањири и друго посуђе. На трави лежи магаре, ваљда једино живо биће у доњој махали (poli010529.txt).

2.3. Неретко говорник, на основу рационалног промишљања, очекује да је пропозиција истинита или да ће се остварити. Његово очекивање засновано је на ономе што је општепознато, уобичајено, правило и сл. Поред епистемичког, речца ваљља у таквим примерима има и евалуативно значење, њоме се исказује оцена. Самим тим носи већи ниво уверености, има вредност глагола требати. Овде долази до изражаја њено порекло. Наиме, А. Белић констатује да речца ваљља, као и речца можда, представља „увек скраћену реченицу или скраћен или сажет њен део (исп. можда = може бити, ваљда, ваљьада = ваља да)" (Белић 1941: 137). ${ }^{4}$

\footnotetext{
${ }^{4}$ Модални глагол ваљати, између осталог, може имати и значење требати, бити потребно, па и бити у складу с обичајима, одговарати обичајима, уобичајеним мерилима. Уп. РСЈ.
} 
...jер наша душа је шпајз. Постоји ваљда некакав ред којим слажемо зимницу. Зна се на којој полици стоје тегле са џемом, а где ајвар и туршија. Код тебе је све испретурано, све постоји истовремено (velikic-sr.xml); Није живот биоскоп. Али и тада, ваљда, сам одабереш филм који желиш да видиш? (velikic-sr.xml); Ако ништа друго, ваљда у Комерцијалној банци постоји траг о томе ко је донео дрогу у трезор који је изнајмила СДБ (poli010317. txt); Ако француска вина могу на тржишту да наступају као 'Вина из Француске', а сиреви као 'Француски сиреви', онда ваљда и исте воде из једног малог места могу размишљати о заједничком освајању домаћег и иностраног тржишта (poli010706.txt); Па, ја сам овако размишљао: ако ме сретне неки паметан милиционер, он ваљда зна да поп на слави мора и да једе и да пије (poli001230.txt).

2.4. Забележени су и примери у којима говорник не сумња у истинитост пропозиције. Лексема ваљда нема функцију да унесе несигурност у исказ, већ управо да нагласи неслагање с туђим поступцима и ставовима који се ишчитавају из контекста. Говорник је револтиран датом ситуацијом.

А колико је то конвертибилних марака, дохвати деда излизан кожни новчаник и пружи 'педесетицу' . - Чега, откуд ја то знам, па у овој земљи се ваљда још увек плаћа динарима - искали сав бес на збуњеном човеку (poli010305.txt); Не би ваљало ослободити сваког пореза издаваче, који у Београду штампају све књиге на латиници. Ваљда је и ћирилица српско писмо (poli010519.txt); ...пожалио (ce) да је ово прво такмичење на коме судије нису добијале макар бесплатну кафу. Штедело се и на пропагандним материјалима. Као да је сваки издатак ишао из приватних џепова. А ваљда је у питању најважнија југословенска шаховска смотра (poli010604.txt); ...па знам ваљда де сам дошо (patrljak.txt); Знам ваљда како да изађем из града (patrljak.txt)

2.5. У грађи се може издвојити група примера у којима ова речца стоји уз предикате с модалним и евалуативним значењем. Уз глаголе морати и требати, који представљају нужност и потребу, смањује интензитет модалног исказа, служи ублажавању тврдњи исказаних овим глаголима. Уз евалуативне предикате тип важно је, приличи, доликује и сл. служи исказивању опреза.

Тако је ваљда морало да буде. Мало лоше среће и ту сам (poli010725.txt); Дужност да невернике преобраћа у вернике и верницима повећава верску образованост треба, ваљда, да има, конкретно, Црква (poli010721.txt); Наш патриотизам је тим генералима увек био несавладива препрека. То би, ваљда, требало да зна и генерал из Југославије, чак иако је у пензији (poli000909.txt); Много је, ваљда, важније што од доласка нове власти у области градње на Златибору нема кршења закона, нема корупције (poli010628.txt); Садашњост је компликована и на самиту ће, како ваљда и доликује таквим церемонијама, као таква бити присутнија на мизансцену него на главној сцени (poli001123.txt); ...у Задужбини Иве Андрића (...) чули су се потпуно дисонантни тонови. Тако, ваљда, и приличи правим научницима (poli001212.txt).

2.6. Неретко се ова речца јавља и за означавање наде у остваривање именоване ситуације. Статус 'наде' дискутабилан је у типологији модалних значења. Исказујући наду говорник исказује и жељу за остваривањем ситуације означене у пропозицији, али и дистанцираност која се тиче уверености у њено остваривање. Другим речима, говорник не зна „како ствари стоје”, али има жељу да оно о чему саопштава пропозицијом буде истинито. Зато појам 
'наде' има и елементе булетичке модалности и елементе епистемичке модалности. ${ }^{6}$ Да би речца ваљда добила значење наде, неопходан је контекст који указује на то да је ситуација исказана пропозицијом у интересу говорника. Тада му је семантички еквивалентан глагол надати се.

Главно је да су се, ето, окућили, а биће ваљда и посла (poli010319.txt); Ваљда ће доћи боља времена (poli010413.txt); У свлачионици се орила песма, клицало 'плави - плави'. Ваљда ће овде бити још таквих тренутака излива радости (poli000821.txt); Ваљда ће се ипак неко сетити да имамо бескрајно паметне и талентоване дечаке и девојчице који заслужују бољу шаховску организацију и боље дане (poli001204.txt); Ваљда ћу коначно наћи мало времена и 'за себе', да припремим своју прву самосталну изложбу скулптура у камену. Ови разни други послови одлажу ту моју жељу (poli010716.txt); Ваљда ће се, каже она, за ову нашу хуманитарну акцију заинтересовати дародавци (poli001219.txt); У мају су ми рекли да дођем у јуну, да би ми евентуално заказали преглед у августу, уколико се у међувремену овај апарат не поквари, па се опет цела листа чекања помера. Ваљда ћу имати среће (poli010701.txt).

\section{3. ЛЕКСЕМА ВАљДА У НЕГИРАНИМ ИСКАЗИМА. У неГИранИМ ис-} казима ова партикула по правилу не носи низак степен уверености, већ управо има значење очекивања да пропозиција није истинита, неверице, негодовања, наде да не постоји или да се неће остварити дата ситуација.

3.1. Говорник очекује да пропозиција није истинита на основу општеприхваћеног или личног става. Истовремено исказује неслагање с евентуалним остварењем пропозиције:

Није ваљда ствар тренутка када и како ће се одавати почаст невиним жртвама (poli000811.txt); Нећемо, ваљда, опет понављати стару праксу (poli001230.txt); Неће ваљда сви они заједно опет да чекају председника републичке владе да обави њихов посао (poli010227.txt); Нећемо ваљда дозволити да у време социјализма и током санкција Уједињених нација беше више иностраних гостовања него сада (poli010625.txt); Неће ваљда сваке године мољакати по свету за плате судијама и инима? (poli010715.txt); Михајловић и чланови правосудних органа нису на тим функцијама ваљда да би неког хапсили због нас, већ због тога што тако закон налаже (poli010425.txt); ...да ли постоји еколошка странка, ако постоји, није ваљда њен циљ само борба за власт (poli010403.txt).

\section{2. У следећим примерима говорник исказује неслагање с претпо- стављеним ставом саговорника:}

Не очекујете ваљда да обезбеђујемо кворум за владу у чијем оснивању не желимо да учествујемо (poli001025.txt); Не мислите, ваљда, да би једном таквом човеку, који је већ био 'ванземаљац' (по Кертесу) приличила Забела (poli001025.txt); Нећете ми ваљда рећи да су кокошке заиста носиле јаја са натписима? (poli000916.txt).

\footnotetext{
${ }^{5}$ Под термином 'булетичка модалност' подразумева се онај тип модалности којим се исказује жеља за остваривањем пропозиције. У литератури се понекад употребљава синонимично с термином 'волитивна модалност' (Нејтс 2016: 39). Од деонтичке модалности разликује се по томе што: а) говорник нема утицаја на саговорника, тј. не може захтевати остваривање радње, б) говорник може своје жеље формулисати и ако не постоји испунитељ жеље и в) говорник може желети и неоствариво, чега може бити свестан (Кифер 2005: 62).

${ }^{6}$ Палмер (Палмер 2001: 13) указује на то да је статус исказа којима се исказују жеље и бојазни дискутабилан. Они су, сматра, делом деонтички, делом епистемички искази. Гивон (према Палмер 2001: 134) разматра 'наду' и 'бојазан' као 'епистемичку жељу' ('epistemic anxiety').
} 
3.3. Говорник зна да пропозиција није истинита. Речцом ваљља не исказује сумњу већ исказу даје ироничан тон.

Ипак, мислим да су несрећне људе негде закопали. Нису их, ваљда, дигли у ваздух (poli010520.txt); Он је такође рекао да је Милошевић знао да Војска држи оружје, јер му је била пред кућом, а ваљда 'гардијска бригада није наоружана праћкама' (poli010403.txt).

3.4. Говорник се нада да се дата ситуација неће остварити, тј. исказује бојазан:

Хоће ли ме овај интервју скупо стајати? Ваљда неће (poli000807.txt); Сад се обелодањује да је објекат грађен са озбиљним грешкама у пројектовању, па је инспекција забранила даље радове. Неће, ваљда, да се нешто слично догоди и са црквеном кућом у порти Храма св. Прокопија (poli001230.txt); ...читаоци, ваљда, неће замерити аутору овог текста што ће цитирати речи негдашњег дописника немачког листа ’Ханделсблат' (poli010311.txt).

4. ЗАКљУЧАК. Анализа грађе показала је да се речцом ваљља, у зависности од текстуалног, па и ситуационог контекста, може исказати не само различит степен уверености у истинитост исказа, већ се њоме могу означити и неепистемичке квалификације. У зависности од поузданости и типова расположивих знања она носи мањи или већи степен вероватноће. Уколико нема поузданих доказа, говорник овом лексемом изражава нижи ниво уверености, спекулише о истинитости исказа. Тада се њена вредност на скали истинитости креће на релацији између модалних показатеља можда и вероватно. Ниво уверености повећава се с повећањем поузданости расположивих знања, као што су, на пример, визуелни докази. У том се случају приближава модалним операторима типа сигурно и очигледно. Релативно висок ниво уверености постоји и када се овом лексемом исказује очекивање засновано на ономе што је општепознато, уобичајено, правило, и тада има вредност глагола требати. Неретко се овом лексемом не исказује ниво поузданости тврдње, него управо служи истицању истинитости при чему је присутно и значење неслагања с датом ситуацијом. Између епистемичке и булетичке модалности налази се значење наде. Грађа показује да се речцом ваљда често исказује и ово значење.

\section{ЛИТЕРАТУРА}

Бајби и др. 1994: J. Bybee et al, The Evolution of Grammar: Tense, aspect, and modality in the languages of the world, Chicago and London: The University of Chicago Press.

Белић 1941: А. Белић, О језичкој природи и језичком развитку, Београд: Српска краљевска академија, Посебна издања, Књига CXXXIV, Философски и филолошки списи, Књига 35.

Бoje 2016: K. Boye, The Expression of Epistemic Modality, in: J. Nuyts and J. van der Auwera (eds.), The Oxford Handbook of Modality and Mood, Oxford: University Press, 117-140. 
Кифер 2005: F. Kiefer, Lehetőség és szükségszerüség. Tanulmányok a nyelvi modalitás köréböl, Budapest: Tinta könyvkiadó.

Мразовић 2009: P. Mrazović, Gramatika srpskog jezika za strance, Sremski Karlovci - Novi Sad: Izdavačka knjižarnica Zorana Stojanovića.

Hejтc 2016: J. Nuyts, Analyses of the Modal Meanings, In: J. Nuyts and J. van der Auwera (eds.) The Oxford Handbook of Modality and Mood, Oxford: University Press, 31-49.

Палмер 2001: F. R. Palmer, Mood and Modality, Second edition, Cambridge: Cambridge University Press.

Пипер 2005: П. Пипер, Предикат и Семантичке категорије у простој реченици: синтаксичка семантика, у: П. Пипер, И. Антонић, В. Ружић, С. Танасић, Љ. Поповић, Б. Тошовић (у редакцији Милке Ивић), Синтакса савременога српског језика, Проста реченица, Београд: Институт за српски језик САНУ, Београдска књига - Нови Сад: Матица српска.

Пипер/Клајн 2013: П. Пипер, И. Клајн, Нормативна граматика српског језика, Нови Сад: Матица српска.

PCJ 2007: Речник српскога језика (ур. Мирослав Николић), Нови Сад: Матица српска.

Станојчић/Поповић 2002: Ж. Станојчић, Љ. Поповић, Граматика српскога језика, Уибеник за I, II, III и IV разред средње школе, осмо, прерађено издање, Београд: Завод за уџбенике и наставна средства.

Стевановић 1964: М. Стевановић, Савремени српскохрватски језик (граматички системи и књижевнојезичка норма), I. Фонетика, Морфологија, Београд: Научно дело.

Трбојевић Милошевић 2004: I. Trbojević-Milošević, Modalnost, sud, iskaz, Epistemička modalnost u engleskom i srpskom jeziku, Beograd: Filološki fakultet.

Dušanka S. Zvekić-Dušanović

ABOUT THE MODAL PARTICLE VALJDA IN THE CONTEXT

Summary

The particle valjda belongs to the semantic group of lexemes, which, primarily, express the epistemic modality. Using the corpus of modern Serbian language, the paper determines the positions it can occupy on the confidence scale, examines its semantic values, which it receives depending on the context, and analyzes the influence of different types of a modal source on its interpretation. The analysis of the corpus has shown that the particle valjda, depending on the context, can express not only a different degree of conviction in the truthfulness of the statement, but it can also denote nonepistematic qualifications. If there is no reliable evidence, the speaker uses this lexeme to express a lower level of conviction, to speculate on the truthfulness of the testimony. In that case, its value on the scale of truthfulness moves between modal indicators možda i verovatno. The level of conviction increases together with the increase of reliability of available knowledge such as, for example, visual evidence. In this case, it comes closer to modular operators of the type sigurno and očigledno. There is a relatively high level of conviction also when this lexeme shows the expectation based on what is 
commonly known, usual, rule, and then it has the value of the epistemically used verb trebati. Not seldom does this lexeme not show the level of reliability of the assertion, but it serves the purpose of emphasizing the truth, whereby the meaning of the disagreement with the given situation is present. Between epistemic and bouletic modality there is the meaning of hope. The corpus shows that the particle valjda often expresses this meaning as well.

Key words: particle valjda, epistemic modality, bouletic modality, semantics, the Serbian language. 